\title{
Female Preachers and the Public Discourse on Islam in Malaysia
}

\author{
Norbani B. Ismail
}

\begin{abstract}
This paper explores Malaysia's activist female preachers (pendakwah) by highlighting the religious authority and leadership in preaching that they have attained due to their firm grounding in Islam's fundamental sources and Arabic. I analyze their recorded online lectures, radio talks, and interviews to identify their common preaching styles and highlighted themes. The study finds that their highest objective is to help create a sound moral and ethical society via the fulfillment of moral and religious obligations. To that end, they deal primarily with spiritual development and family management issues, as well as draw spiritual and religious conclusions from important historical events. The paper concludes that they keep their activism within the confines of expected social norms and the bureaucracy of religious authority. By adhering to social and religious orthodoxy, they continue to gain authority and trust from both the established religious authorities and the public.
\end{abstract}

\section{Introduction}

Since becoming independent in 1957, Malaysia has sought to empower women through mandating gender equality and equal access to education. As a result, they have acquired a more public role and contributed to the nation's socio-economic and political development. The 1980s may be considered the

\footnotetext{
Norbani B. Ismail is a visiting Malaysia Chair of Islam in Southeast Asia at Prince al-Waleed bin Talal Center for Muslim-Christian Understanding, School of Foreign Services, Georgetown University, DC. Her research interests include the interpretation of the Qur'an in Indonesia and Egypt, Muslim women's religious activism in Malaysia, and trends of Islamic reform in contemporary Southeast Asia. This research paper was partially funded in 2009-2010 by the Research Management Center, International Islamic University Malaysia, Malaysia.
} 
beginning of an era of mass media-based religious activism. Previously, religious scholars used to preach at local mosques and private events; now they have their own television and radio shows, and their religious views are published in newspapers and magazines. Qualified female preachers are fully engaged in religious activism, given the same space and opportunity as their male counterparts, and address mixed-gender audiences on issues essential to daily life (e.g., the daily obligatory prayers, fasting, pilgrimage, charity, spiritual enhancement, family, marriage, and parenting).

This paper explores the activities of several well-known female preachers (pendakwah), ${ }^{1}$ through their use of the mass and social media, to the religious discourse occurring in Malaysia and how they obtained the public's trust and their authoritative voice. I contend that such women pursue this path to fulfill their religious duty by diffusing religious knowledge to help create a society that upholds sound moral and ethical standards. Moreover, I focus on their desire to both transform themselves and help their society move toward Islamic piety by encouraging the people to fulfill their moral obligations.

To the best of my knowledge, hardly any academic attention has been directed toward "unaffiliated" women who do not officially represent the country's Islamic and social movements, but whose works are nevertheless changing its landscape of religious discourse. The present study seeks to understand the enabling factors that have facilitated this type of activism by examining the works of three well-known female preachers, namely, Siti Nor Bahyah Mahmood (b. 1966), Sharifah Hayati Syed Ismail (b. 1969), and Fatmaa el-Zahraa Mohammad Ramadan (b. 1947), through their televised media appearances, magazine articles, and online social media. It also explores the motivation of why they engage in religious discourse.

The work of these religious activists is limited to knowledge diffusion, for they are not part of the higher religious hierarchy of Malaysia's established religious authority. Saba Mahmood has noted that western liberal theories define women's agency as the "capacity to realize one's own interests against the weight of custom, tradition, transcendental will, or other obstacles (whether individual or collective)." " However, she argues that this agency should not be understood solely as freeing oneself from the shackles of this bond, but also as something that takes into consideration the piety and modesty that shaped their decision. ${ }^{3}$ In the context of female preachers, their training in religion has not only enabled them to understand the obligation of acquiring knowledge, but also of passing it on to their audiences to create a morally and ethically sound society. They have demonstrated that preaching activities re- 
quire some element of agency that must be understood within their cultural milieu.

The ethical and moral formation and transformation that these women underwent during their religious training, which gives them the authority to speak about Islam and the ability to influence others, can also be understood as "ethical agency." This very act of generating change in oneself and others through this ethical and moral formation is, in fact, forming "ethical agency," which differs from "political agency" as understood within the context of progressive politics. ${ }^{4}$ Furthermore, even though these preachers are absent from the established religious hierarchy's higher levels - a sign of acquiescence to male domination - the very fact that their personal piety drives them to preach, hand-in-hand with their male counterparts, indicates their empowering will to challenge the status quo.

Jeanette S. Jouili and Schirin Amir-Moazami's study on women's religious activism in Germany and France has shown that Muslim women gain their interpretive authority through their own knowledge and training. ${ }^{5}$ In fact, these three women's possession and subsequent diffusing of authoritative knowledge, not to mention their authority and leadership in religious knowledge, conferred the necessary power upon them. This intricate link between authority and knowledge diffusion can only be achieved by examining their works, which will reveal how they draw their conclusions. Their authority to speak about Islam to the public is based upon their mastery of the material. This is partly due to their eloquent speeches, which are presented in a soft yet very firm voice. Their authoritative voice is also partly due to their ability to quote the appropriate Islamic texts in perfect Arabic and to draw conclusions from Islam's authoritative sources. Many of the issues raised during their presentations and their ensuing advice, carried by all of the usual media outlets, are embedded in Malaysia's established religious orthodoxy.

Hilary Kalmbach's study of female Muslim activists in Damascus explored their conformity to society's moral conventions and the advantage they gained thereby, such as keeping their present authority, even though they may sometimes view those codes as suppressive. However, the very act of compromising with and conforming to the indigenous social norms enabled them to perceptively restructure the previously male-dominated realm of preaching. Thus their compliance essentially gave them more freedom to engage in this type of activism, albeit with some conventional limitations. ${ }^{6}$ By conforming to the state-defined religious orthodoxy, not only are they allowed to preach, but they are also able to retain their present knowledge-based religious authority. 


\section{Muslim Women and Knowledge-based Religious Authority}

Historically, religious scholars (ulema) have frequently been agents of sociomoral change. Their authority usually has been on matters related to religious doctrine and law, since these are their fields of expertise. ${ }^{7}$ Society in general accords them respect due to their often long and diligent religious training, which enables them to comprehend religious matters that are beyond the ordinary Muslim's understanding. ${ }^{8}$ Furthermore, they have earned the public's trust and their own authority by traditionally remaining political neutral and issuing independent judgements. ${ }^{9}$ To ensure that accurate knowledge would reach people as many as possible, the ulema often delegated their responsibilities to teach religion to imams, khatībs (preachers), Qur'an reciters, and other learned individuals. ${ }^{10}$

During the first few centuries of Islam, Muslim women had the right to acquire knowledge and subsequently gained the authority to teach others. ${ }^{11}$ Tracing their active participation in this regard is possible due to the existence of biographical dictionaries of Muslim scholars. In her work on the biographical collections of Muslim women, Ruth Roded noted the varied contributions made by the female Companions. For example, Aisha became an important reference for the Madinan community in many branches of knowledge. She transmitted 1,210 hadiths, was consulted on matters of law, and her fatwas were referred to during the reigns of Umar and Uthman. ${ }^{12}$

However, after the second generation their roles and positions in the knowledge hierarchy decreased, even though they still taught men who would go on to become great scholars. ${ }^{13}$ From the sixteenth century onward, the number of women mentioned in biographical works dwindled - a situation perceived as their diminishing role in public. In modern times, they could not teach male students and their knowledge authority became restricted, for they generally received only a home-based informal religious education from other women. Consequently, their limited access to public educational institutions added to their difficulties in acquiring any type of scholarly religious authority. ${ }^{14}$

A recent work on women and religious authority in Islam has shown a remarkable shift away from this stagnation of intellectual and preaching activities. Kalmbach has pointed out that female religious instructors in the mosques of Damascus have gained respect and been authorized to educate, teach, and guide their female audiences. This encouraging development can be attributed to the educational institutions' granting women access to religious training during the twentieth century. ${ }^{15}$ But despite this greater ability 
to engage in knowledge transmission, some authoritative women still feel that they are not allowed (by men) to speak about Islam even to their female audiences, because men do not consider them competent. ${ }^{16}$

\section{Women and Education in Malaysia}

Muslim women in Malaysia have been free to actively engage in public activities since the beginning of the twentieth century. ${ }^{17}$ Malay ${ }^{18}$ women are found in the business sector, are good leaders, and have full inheritance rights. They are free to move about, as "there is no purdah" system among the Malays - these women move about with perfect freedom with their heads although may be covered, with faces only slightly veiled by a shawl. They laugh, chat, and (often) flirt with the other sex in ways that other Muslim women in most Muslim countries would not dare to do." ${ }^{20}$ However, their freedom has often been understood and acted upon within their society's allowable norms, as dictated by Islam and Malay culture. "The relationship between the two opposite genders was formed within what [is] commonly accepted by all the Eastern traditions[,] whereby it was based on the idea of modesty on her part and of solitude for her safety and honor on the part of the man." ${ }^{21}$ In politics, many parties have made a concerted effort to involve them in public spaces. ${ }^{22}$ Women have earned society's trust as change agents in the nation's political, economic, and social agendas. ${ }^{23}$

In terms of education, Malaysian women have accomplished great things since the country became independent. ${ }^{24} \mathrm{~A}$ report released by the Malaysian Higher Education Ministry in 2010 showed that they accounted for 58.9 percent of postgraduate students enrolled at public universities and 61.40 percent of undergraduate students. ${ }^{25}$ Likewise, they have acquired religious education at both local and international universities, which has increased their access to religious activism and knowledge proliferation. ${ }^{26}$

In terms of social activism, women have been organizing themselves into social associations since the $1950 \mathrm{~s}$. Some of them were sent abroad to learn how to manage organizations that promoted women's causes and, upon returning home, motivated others to start claiming their rights. ${ }^{27}$ As a result of this proactive approach, these women managed to get the relevant government authorities to consider their concerns and issues. Armed with their educational qualifications and training skills, they entered the economic sphere and become important contributors to the country's industrialization. ${ }^{28}$ The preceding paragraphs have discussed equal access to opportunities in education, which has enabled qualified Malaysian women to enter public roles in various fields. 


\section{The Official Administration of Islam in Malaysia}

After the Malacca sultanate fell to the Portuguese in 1511, Islam retained its special position and was protected by the smaller sultanate of the Malay rulers. The colonialist ruler's policy of non-interference in matters of family law and local customs, also adopted by the Japanese during their short occupation (1941-45), placed Islam in a high position. Constitutionally, Islam "is the religion of [the] federation in which the Muslims' rights are protected; the non-Muslims are prohibited to propagate other religions to the Muslims; and the state revenue such as tax is permissible to assist Islam." ${ }^{29}$ Under the British, the traditional Malay rulers maintained their protective control of Islam, even though this eventually allowed Britain to control its colonial subjects and tailor the rulings and decisions to the ideals of British judicial practice. ${ }^{30}$ In fact, they had to approve many of the regulatory ordinances, among them the appointment of $q \bar{a} \underline{d} \bar{\imath} \mathrm{s}$ (judges) and imams, rulings on fornication, mosques attendance, and matters related to marriage and divorce. During that time, William R. Roff described Islam and its affairs as being very much structured and bureaucratized in order to "encourage the concentration of doctrinal and administrative religious authority in the hands of a hierarchy of officials directly dependent on the sultanate establishments for their position and power." 31

From 1957 onward, Islam in Malaysia has been managed in a similar way. In the former Strait Settlements (Malacca and Penang) and the Federal Territories (non-monarchical states), Islam's hierarchical authorities have a vertical structure. The highest authority is the Yang di Pertuan Agong ${ }^{32}$ (Malay Supreme Ruler), who is elected by the traditional Malay rulers every five years. Each state has a Majlis Agama (Religious Council), headed by a mufti, that advises the Malay ruler on such Islamic affairs as zakat collection, marriage and divorce, Muslim offences, appointing or discharging the $q \bar{a} d \bar{l}$, issuing fatwas, and certifying Islamic teachers. Additionally, each state has a Pejabat Agama (Department of Religion), an enforcement body that helps the Religious Council operate the day-to-day Islamic matters and assist Shari'ah) courts. ${ }^{33}$ On the other hand, in the monarchical states the sultan is the highest authority. The Religious Council and the state's Department of Religion each assume the same duties and jurisdictions as do their counterparts in the nonmonarchical states. In addition, Malaysia also has a Jabatan Kemajuan Islam Malaysia (Department of Islamic Development Malaysia), ${ }^{34}$ which is under the direct administration of the ruling government, more specifically, the Office of the Prime Minister. ${ }^{35}$ 
The global Islamic resurgence, which has also impacted Malaysia, ${ }^{36}$ has been instrumental in enforcing a stricter adherence to Islamic values in the government policy-making, educational, socio-cultural, and politico-economic spheres in public spaces. ${ }^{37}$ Under Mahathir Mohamad's premiership, (19812003) the government supported Islam-related initiatives; prior to this, foreign policy had been geared toward the West. ${ }^{38}$ Thus, Islam now plays a greater role at the personal, societal, and governmental levels. ${ }^{39}$ The previous illustrations highlight the factors that allude to those political socio-religious backdrops that have facilitated Muslim women's preaching activities in the country.

\section{Female Preachers in Malaysia: Establishing Religious Authority}

The trend of preaching ${ }^{40}$ and learning about Islam via the mass media, which started in the 1980s, was a global phenomenon ${ }^{41}$ in that it allowed preachers to reach a wider audience regardless of class, gender, and age group. In Malaysia, both the state-owned and privately owned media have increased their Islamicoriented programs to meet the growing demand for them. ${ }^{42}$ Malaysian Muslims, increasingly aware of their identity, wish to experience and explore everything Islamic, including Islamic forms of entertainment and learning about Islam not only in mosques and classrooms, but also from cassette tapes and writings. ${ }^{43}$ Religious scholars have newspaper columns, as well as monthly and weekly magazines, and deliver lectures on television and radio programs. The mass media gives space for female preachers to convey Islam's message, and television and radio stations have allocated more airtime for them. Women's involvement in preaching took off during the late 1990s when they were invited to be on panels for public religious events or to appear on prime-time weekly religious television programs (e.g., Alkuliyyah and Forum Perdana Ehwal Islam) and had their opinions published in Islamic or women's magazines (e.g., Al-Islam, Anis, Mingguan Wanita, and Nur).

Given that Malaysia regulates the preaching of Islam, one must obtain a tauliah (Malay: authorization) from the authorities to speak about it at any public gathering, even if it is held at a small residential surau, ${ }^{44}$ mosque, or school. One also needs an authorization to give a khutbah (sermon) during the Friday congregational prayer. ${ }^{45}$ Whoever ignore these rules has his/her authorization revoked and is penalized. ${ }^{46}$ The state religious councils justify this approach on the grounds that they must be able to distinguish "legitimate" preachers from those motivational speakers who (mis)use Islam as a marketing strategy. ${ }^{47}$ This authorization seeks to regulate preaching activities and super- 
vises Islamic teachings so that they will remain within the sphere of orthodoxy; however, the preachers' speechers are not necessarily strictly vetted.

This authorization process, which has been standardized nationwide, helps the councils identify qualified people, even though at times its application might be seen as strict and lacking in discretional judgment. For instance, in 2009 the police detained and questioned Muhammad Asri, ${ }^{48}$ a former mufti of the State of Perlis, after he refused to cooperate with the Department of Religion's officers for speaking about Islam to almost 500 people at a private home in Selangor without the state's tauliah. While Asri did not secure the required authorization, one might wonder about the motive behind such a reprimand, for he was supposedly highly qualified to give such a talk. ${ }^{49}$ Many interpreted the council's action as not only an example of poor discretion by the state's religious apparatus, but also viewed it as politically motivated. Others saw it as an attempt to silence people whose interpretation of Islam differed from the country's traditional practice and understanding. ${ }^{50}$

The brief illustrations above are instrumental in describing how the teaching, understanding, and interpreting of Islam are, to some extent, controlled in order to maintain religious coherence and harmony. ${ }^{51}$ As a corollary, preachers in Malaysia are expected to conform to these officially sanctioned sensibilities of religious orthodoxy. It is also noticeable that all of these religious apparatuses, from the mosques to the religious councils, are led by men. ${ }^{52}$ Female preachers have to operate within these religious cultures and sentiments, and therefore must be sensitive not only to society's socio-cultural sensibilities, but also to the politics of interpreting and expressing one's opinion of Islam.

The following pages will explore three women who preach via the mass media but represent no specific Islamic movement or organization: Siti Nor Bahyah Mahmood, Sharifah Hayati Syed Ismail, and Fatmaa el-Zahraa Mohammad Ramadan. They will be referred to by their first names. Nor Bahyah has a B.A. in Islamic studies and Arabic language from al-Azhar University. She and her husband own SNB Kasih, a consulting firm that provides Islambased programs and training for officers and individuals. In addition, she has authored eight books, mostly on family management and spirituality. ${ }^{53}$ Hayati has a Ph.D. in management from Bristol University, UK; however, her first degree was in Islamic studies. She is currently an associate professor at the Academy of Islamic Studies, University of Malaya, and has written two books on good governance. ${ }^{54}$ Fatmaa has a B.A. in dentistry from the University of Newcastle, UK, as well as a homeschooled certificate in Islamic studies from al-Azhar University. ${ }^{55}$ She is an Egyptian, but has been a per- 
manent resident of Malaysia since 1971 and is fluent in English and colloquial Malay.

Based on their qualifications, it is safe to say that they are fluent in Arabic and therefore have direct access to Islam's fundamental sources. Their knowledge about Islam and these sources is apparent in their ability to quote the Qur'an and the hadith in Arabic. Their preaching engagements take the form of television appearances and radio talk shows, as well as invited participants in seminars and writers in newspaper columns and magazines. ${ }^{56}$ Lately, their lectures have been uploaded to such online sites as YouTube. Their presence and popularity have become ubiquitous, for people from all walks of life, regardless of class, gender, or age group, recognize them. In addition, their names are often mentioned in conversations at coffee shops, the farmers market, and office cubicles. ${ }^{57}$ These preachers have won their audiences' hearts by being very confident in their talks and expressing themselves in a soft yet firm tone. They usually sit next to other male preachers and address mixedgender audiences, which is the norm in Southeast Asian Muslim societies. Furthermore, their ability to convey Islam's message and that of its fundamental texts in vernacular Malay, as well as to express their views within the framework of the public discourse on Islam, has further popularized their work.

One may notice that these women deal with a wide range of themes and topics that are vital to the public in terms of their day-to-day praxis and moralethical uprightness, such as spiritual fulfillment and purification, in which daily supplication $(d h i k r)$ is part of the training. Occasionally they also focus on issues related to special dates in calendar, such as the Prophet's hijrah and its relevance to contemporary Muslims, Ramadan, and the Prophet's isrā 'and $m i$ ' $r a \bar{j} j$ (miraculous night journey). As one can see, they direct their lectures toward building the audience's Islamic character and identity.

One important topic is that of family management. As women in general have access to the type of education that eventually leads to qualification, both women and men contribute to the family's financial wellbeing. While working outside the home is often necessary for women, more often than not they feel the burden to create and maintain a happy family. Their struggle in juggling both sets of expectations often causes emotional stress.

Nor Bahyah is a role model in this regard, for she is an emphatic supporter, a practical socio-moral guide, and a charismatic preacher. She shows her empathy for these women by lending her emotional support and expressing concern about the burden imposed by traditional expectations of women being responsible for ensuring marital happiness. Fully aware that her au- 
diences comprise both husbands and wives, she underlines that marital happiness should be a mutual effort. For example, she suggests that husbands share the household tasks and chores, an idea that might be at odds with the traditional gender-based division of domestic labor. She also criticizes the remaining traces of the now almost-abandoned culture of different behavioral and gender-based expectations, such as exempting boys from the household chores, as "un-Islamic" on the ground that such training helps out the family as a whole. Moreover, these boys are essential to the family's wellbeing because as husbands they will share the household duties with their wives, just as the Prophet did. ${ }^{58}$ Here, Nor Bahyah uses the historical narrative and such fundamental texts as the Hadith literature to develop her argument.

During one event Nor Bahyah was sitting next to her husband, who often shares the stage with her. ${ }^{59}$ In a convincing, confident yet eloquent voice, she began her lecture on the power of prayer $\left(d u^{\prime} \bar{a}^{\prime}\right)$ and recited Q. $27: 30-33^{60} \mathrm{in}$ Arabic to describe the story of Sulayman and the Queen of Sheba. She used persuasive communication to relate to her audience the power of one's faith in God's will through prayers. The queen was described as powerful but very arrogant toward God. But Sulayman, a man of strong faith, was convinced that God's grace would change her heart. Nor Bahyah pointed out that Sulayman's good intention and strong faith was a powerful combination that might help persuade the doubtful queen. She reminded the attendees that it has been proven that these verses are powerful enough to remove doubts and strengthen one's belief. ${ }^{61}$

Here, Nor Bahyah attempted to instill a spiritual character in her audience via an easily understood vernacular. This story was treated not only as a Qur'anic moral and spiritual communication from the past to the present, but also as a way to build a strong spirituality based upon the noble characters portrayed. In addition, she applied her personal experience by stating her belief that reciting these verses helped her wish come true. ${ }^{62}$ Nor Bahyah ended the lecture by asking her audience in a very persuasive manner if they were convinced that God would always respond to one's prayers by saying "Hebat tak doa?" (Aren't prayers powerful?).

In another audio talk, she explained how this life is a test from God, who tests people with wealth and health, poverty and sickness. One must be patient when faced with difficulties and grateful when blessed with God's favors, for both of these attitudes earn God's pleasure. She reminded her listeners that God tests people not to punish them, but to train them to react patiently to the divine plan and will. Here Nor Bahyah sought to shape her audiences' theo- 
logical understanding by urging them to have good assumptions toward God and a proper understanding of His love. In terms of the latter, this love may not necessarily be manifested only through His favors, but also through His pleasure with their patience during hard times. ${ }^{63}$

At a local community hall located in a middle-class neighborhood in a Kuala Lumpur suburb, Hayati was seen sitting next to a female announcer while addressing a mixed-gender crowd. She had been invited to this event, held in conjunction with the Prophet's birthday, to explain how to follow the Prophet. She began by praising the people for coming, for doing so emulated the life of the Prophet, who had encouraged everyone to seek knowledge. She talked about how the Prophet was their best role model in all aspects and articulated those characteristics that made him the model husband and then conceptualized the meaning of following the Prophet by emulating his characteristics, among them treating his wives with respect and equality. These qualities were emphasized to give her audience an idea of how Islam defines the best spouse. Through this technique, she sought to inspire the husbands to imitate the Prophet and to give the wives an idea of how an ideal husband should behave.

Hayati went onto persuade the attendees to strive to imitate the Prophet's good behavior in this regard in order to earn happiness in this world and in the hereafter. By emulating his behavior in their marital life, the parents would be able to create a happy family, a baytī jannatī (my house, my paradise), that would earn the barakah (divine grace). In this way, they would increase their happiness, just as if they were already living in paradise.$^{64}$ In this lecture, she expounded upon the meaning of modeling one's behavior upon that of the Prophet in a way that those listening to her could easily emulate in their daily lives. After employing examples, concepts, and vocabulary that were easy to understand and pragmatic, she then placed her conclusions solidly within the orthodox Islamic framework.

Inevitably, these female preachers receive many questions concerning women, from managing family life to choosing one's spouse. Many Malaysian women pay a lot of attention to the hijab, which comes in various styles and colors that suit indigenous fashion designs, although wearing it is not strictly enforced. However, some question whether their choice of hijab meets the religious requirements. Hayati corrected this confusion by arguing from the perspective of its purpose, namely, wearing modest attire. Dressing modestly means covering the whole body, except the palms ${ }^{65}$ with clothes that are neither figure-hugging nor transparent. She reminded the audience that although one's hijab necessarily means covering one's hair, it may not 
be modest ${ }^{66}$ for some Malaysian women emphasize its physical form. Here, Hayati supported her conclusions by deriving the moral-legal values from the prophetic hadith.

In relation to modesty, these preachers also deal with the issue of female beauty. Based on an interview published in a women's magazine, both Nor Bahyah and Hayati explored the concept of beauty from Islam's moral and spiritual dimensions. Nor Bahyah reminded her audiences that every aspect of a woman's body, including her beauty, was a test and that any misuse of it might cause her to deviate from God. ${ }^{67}$ She then utilized the Qur'anic narration of Zulaykha, the beautiful wife of Pharaoh's chief minister, and Prophet Yusuf to point out the triumph of one's inner spiritual strength over superficial appearance. Yusuf was a moral person who had strong faith in God, whereas Zulaykha was a person of questionable moral standing. He remained spiritually strong, despite her plot to win his heart through her physical charms. Nor Bahyah concluded that Yusuf only married Zulaykha after she became a believer ${ }^{68}$ Here, she redefined the meaning of beauty: It should not be understood as physical beauty alone, but, more importantly, as a person's spiritual and moral standing.

Hayati's definition of beauty focused on one's personality, that is, a beautiful person characterized by a wholesome personality: moral uprightness, true faith, intellectual competence, and constructive engagement with one's community. She argued that a woman's beauty is manifested not just in her physical appearance, but also in her positive outlook toward the world and resilience in facing challenges. She narrated the story of Hajar, who was abandoned by her husband Prophet Ibrahim in the desert along with their first-born son Ismail. A strong person, Hajar displayed her patience, positive attitude, and strong faith in God's decision in how she dealt with her new reality. Today's women should emulate her positive character in their daily lives. Hayati's elaboration on the meaning of beauty reflected her awareness of materialism's impact upon contemporary Muslims. She asserted that a Muslim woman must possess qualities such as haya ' (modesty) and self-respect, for these are essential characteristics of beautiful people. ${ }^{69}$

The responses of Nor Bahyah and Hayati show their ability to prescribe answers that could be seen as an attempt to locate the noble characters mentioned in the Qur'an in modern life and draw conclusions that respond to changing realities within the Islamic framework, even if there are no explicit texts on such matters.

In a small forum, Fatmaa was speaking in a mix of colloquial Malay and English to her women-only apparently English-educated audience. ${ }^{70}$ 
She opened by explaining the importance of seeking knowledge so that one could know her God and went on to remark that Muslims have a very comprehensive reference for their lives, because the Qur'an is "a book that has everything." For example, one who knows Sürat al-Baqarah will know how to live life due to the moral, legal, and historical guidance it contains. Focusing on Q. 24:1-15, Fatmaa explained that it provided guidance for all of Malaysia's social problems, among them adultery, baby dumping, and gender mixing. She cited the occasion of revelation (sabab al-nuzūl) of verse 11, believed to be about Aisha, who was rumored to have committed adultery. ${ }^{71}$

Fatmaa also argued that the moral and social guideline contained in these verses, such as asking permission to enter someone's house and women dressing modestly, would help prevent zina (adultery/fornication). According to her, women's public behavior (e.g., how she walks and talks) must be modest because it is the "key" to adultery as what she does may attract unnecessary attention from male strangers. Aware that some people think such an idea might restrict women's behavior and freedom, she stated that Muslims should not behave like mat saleh (a generic term for westerners or white people, who are often assumed to be lacking in morality) because they have divine rules to follow. ${ }^{72}$ Here she apparently made a general conclusion about westerners to emphasize that her audience should adhere to the Qur'an's superior moral guidance. Perhaps such "othering" can be seen as an attempt to internalize the self-confidence of the faithful.

She also talked about the Qur'anic verses' virtues and impact upon a person's psychological, spiritual, and emotional dimensions. If these verses were regularly exercised as recommended practices, one would gain the benefits associated with them. She argued that since the Qur'an claims to be the healer (shifa $\bar{a}^{\prime}$ ), as mentioned in Q. 16:6973 and Q. 17:82, ${ }^{74}$ these exercises can heal any psychological, emotional, or spiritual issues if they are practiced diligently, such as reciting particular verses after the obligatory or voluntary prayers. An article in a women's magazine quotes her as having suggested that one may "soften" one's heart to perceive the Truth of God by reciting Q. 59:21, ${ }^{75} \mathrm{Q}$. 20:1-6, ${ }^{76}$ and Q. 2:255, as well as sūrahs al-Fätihah, al-Ikhlās, al-Kāfirūn, and $a l-N \bar{a} s$, in their entirety. One must end this exercise with a supplication to God to soften one's heart, just like God softened the iron of Prophet Dawud. ${ }^{77}$ From these examples, Fatmaa's approach to preaching was noticeably geared toward encouraging her audience to have a relationship with the Qur'an. Those short verses and chapters are easy to memorize and practice on daily basis by people who have only a little knowledge about the Qur'an. 
Nor Bahyah shares this approach of introducing the Qur'an to the public on a different scale. She believes that Muslim parents need to include the Qur'an while educating their children. Reciting its verses should be obligatory so that a culture of remembering God at home can be created. Every family member should be able to recite the verses in Arabic. Realizing that most Malay Muslims find it difficult to understand the Qur'an in Arabic, she pointed out that a person must consult Malay or English translations to both understand and practice its messages. She also recommended reciting the first chapter before starting or doing anything, for doing so will protect one from harm, provide the inner strength to face life's challenges, and help one become more decent. However, she did not elaborate further on the matter. ${ }^{78}$ Nor Bahyah's conclusions on the importance of acquainting oneself with the Qur'an is justified by a narration from the Prophet, in which he was reported as having described the Qur'an as illuminating the grave of one who had recited it on a daily basis. ${ }^{79}$

These female preachers do not restrict their work to family- and womenrelated issues only. For example, Hayati discusses the Prophet's migration and life, fasting, pilgrimage, and any other topics that she deems relevant to her listeners and the general public. During the pilgrimage season, all preachers should talk about the pilgrimage so that those who attend their lecturers can understand the lessons and conclusions to be learned from its rituals. ${ }^{80}$

The above examples demonstrate these women's knowledge and use of core Islamic texts to explain the issues with which they deal, and also reveal that they have enough command of the material to derive conclusions from Islam's early days and make those events relevant to modern life. Their responses show that they are aware of the ongoing debates and the discourse of canonical issues. Their use of rhetorical arguments spoken in the vernacular language clearly penetrated their audiences' minds. While their delivery styles may have somewhat contributed to their authority in preaching, according to Saba Mahmood their mastery of Islam's core sources helped them gain acceptance and authority among the general public. ${ }^{81}$ Since authority in knowledge is not coercive in nature, their audiences have the power to decide whether to accept or reject the conclusions reached. ${ }^{82}$

\section{Empowering Women through Preaching Activism}

In Malaysia, men dominate the higher hierarchy of religious authority. Women may be involved in religious activities, but only at the lower hierarchical levels and in non-leadership roles. Despite their marginalization, however, they have 
never questioned such domination; in fact, they have acquiesced to this sociocultural arrangement and conform to the related expectations when preaching. Such an attitude can be interpreted as their lack of interest in securing such a status, given that they mainly concentrate on providing orthodox Islamic religio-moral and social-ethical guidance to the public. Fatmaa considered her preaching activities as a response to the Prophet's saying: "Convey from me, even one verse." 83

Female preachers do not consider their activity as grounds for a power struggle, but rather as complementing that of their male counterparts. Their activism makes a serious impact, especially in regard to other women, because they feel comfortable listening to and seeking advice from these preachers. As Hayati articulated, "only women understand other women." 84 This sentiment was echoed by another preacher who believed that she benefits women because "we (women) need women preachers rather than men (preachers), ... because they (men) don't face what we are facing - health problems, how to manage the house, how to manage the children. The woman (preacher) knows better (about other women's concerns). ${ }^{85}$

From these remarks, one can sense the strength and relevance of female preachers to the discourse of Islam in Malaysia, particularly to women. Their strength lies in their ability to provide moral-ethical and religious standards and, most importantly, empathize with the day-to-day struggles faced by women in general. While the former skill and knowledge are necessarily genderless in nature, the latter is perceived as a specifically gender-related aptitude that is not found among male preachers.

Female preachers clearly seek to help other women navigate their daily lives. Through their activities, they have gained not only the trust but also the religious authority from their female audiences. In turn, these audiences can relate to these preachers because the latter also function as mothers, wives, activists, and professionals. Moreover, they are living examples that women do not have to choose between domestic roles or professional careers, that they can actually have both. However, Nor Bahyah and Fatmaa mention the need to juggle multiples roles ${ }^{86}$ They preach not only through their words, but also through how they function in daily life. They inform women of the importance of receiving support from other family members. For example, Hayati views her husband as the "backbone" of her work due to his constant support. ${ }^{87}$

Saba Mahmood has pointed out that women should act upon their ethical agency, for doing so helps create the ethical formation by which they judge their ethics that are, in turn, based upon the virtues and teachings informed 
by Islamic traditions. This very agency enables them to enact and follow their moral obligations freely, without being forced to do so by any authority. These women possess a strong "individualizing impetus that requires each person to adopt a set of ascetic practices for shaping moral conduct." 88

As representatives of ethical agency, the female preachers cited in this study both transformed themselves and helped others do the same through their moral displays and authoritative words that "seek to cultivate a collective practice of piety." ${ }^{99}$ Their conviction strengthened by a strong belief in moral obligation, these female preachers chose not to contest the maledominated status quo, but rather to act within the confines of the country's existing cultural norms. They remained steadfast in their approach in order to create something that was meaningful to them and their society. Their conformity can also be understood as the officially sanctioned portrayal of how a Muslim woman should engage in public preaching in Malaysia. It also gives an idea that although women have a degree of freedom in public spaces, their behavior is always regulated by social norms that they should not transgress.

Muslim women who actively educate others about Islam are not necessarily motivated to challenge the established status of male religious scholars or to obtain leadership roles through their legitimate religious authority. Rather, as Jouili and Amir-Moazami have argued, their goal is to disseminate Islamic teachings as understood within the norms informed by the local religious scholars. They "don't want to 'renew' Islam, but stay inside the 'consensus' of established orthodoxy." ${ }^{0}$ Renewing Islam includes demanding that women's position in the established structure of the religious authorities in Muslim society be reinterpreted or calling for a radical reinterpretation of Islamic texts. The journey of these women who have learned and now teach Islam to others was motivated by their desire to disseminate moral and ethical values. For them, the highest attainment of spirituality and faith can be achieved through intangible means, that is, by enacting one's personal religious obligations and building a Muslim community based upon the ideals of Islam. $^{91}$

\section{Conclusion}

Female Muslim preachers in Malaysia have contributed greatly to spreading the established teachings of Islam, in line with the interpretation sanctioned by the official religious institutions, to the general public through the mass media. Their appearances and views are broadcast via television programs, radio talk 
shows, print media, and Internet websites - all of which provide a platform for conveying their messages to the public. Their efforts have paved the way for other religious activities by women. As a result, more women have become involved in diffusing knowledge through television and radio programs.

This study shows that these preachers' success can be attributed to their support of Malaysia's religious authority. At a national symposium held in 2012, a resolution was passed to establish a secretariat that would facilitate such activism. This secretariat would be placed under the jurisdiction of the Malaysian Department of Islamic Development (Jabatan Kemajuan Islam Malaysia [JAKIM]), the federal department responsible for the country's Islamic affairs and for providing financial and logistical support to female preachers. ${ }^{92}$ This symposium revealed just how powerful their voices had become, for they were now demanding governmental support for their work. Important local religious figures have recognized these women's important contribution in terms of disseminating Islam's teachings. For example, the mufti of Perak state was quoted as saying that he approved of and recognized the work of female preachers, whose numbers are growing, in helping to educate the public about Islam. ${ }^{93}$

The opportunities given to them can be interpreted as a sign of democratization of the usually male-dominated religious authority. These preachers' obvious skills and knowledge have earned them the trust of not only the public, but also of the country's formal Islamic authority. However, they must be careful not to cross the established lines in a system full of intricate complexities; they must respect the authority of the official interpretation of Islam and remain within the country's cultural norms. Given this reality, obtaining the tauliah (authorization) to speak about Islam and how it is understood in terms of the orthodoxy defined by the country's Islamic institutions is necessary.

The activities of female preachers have helped us understand their desire not only to help other Muslims navigate their spiritual and religious lives, but also to become their life coaches. They tell their audiences about the best ways to manage their busy lives by juggling multiple roles in this fastpaced world and that every family member plays an important role in making the home a happy place. In short, they advise their followers about how to achieve happiness and tranquility both in this world and in the hereafter. Their preaching is oriented toward forming the Muslim personality through a spiritual transformation and fortitude, an approach that ultimately disengages them from the political and economic discourse taking place in the country. Such an attitude could be attributed to the idea that they understand 
preaching primarily in terms of creating a religious personality and spiritual formation.

In addition, they have helped frame, shape, and negotiate the identity of Muslim women living in Malaysia by instructing their audiences on how to live a modern life without compromising their faith. These preachers' adherence to religious orthodoxy and the established religious authority indicate that their activism is not just about fulfilling their religious duty to transmit knowledge; it also denotes their conformity to social expectations of how a female preacher should behave. This is clearly seen in Malaysia, where Muslim "women are comfortable with more conservative interpretations of Islam simply because it is couched as their duty, as correct behavior by religious teachers, by [the] ulema, and by those who speak and write with authority on Islam." 94

\section{Endnotes}

1. Pendakwah refers to someone who engages in preaching activities. It is a loan word borrowed from Arabic da 'wah (invitation).

2. Saba Mahmood, "Feminist Theory, Embodiment, and the Docile Agent: Some Reflections on the Egyptian Islamic Revival," Cultural Anthropology, 16, no. 2 (May 2006), 206.

3. Ibid., 209.

4. Saba Mahmood, Politics of Piety: The Islamic Revival and the Feminist Subject (Princeton: Princeton University Press, 2005), 34.

5. Jeanette S. Jouili and Schirin Amir-Moazami, "Knowledge, Empowerment and Religious Authority among Pious Muslim Women in France and Germany," The Muslim World 96, no. 4 (2006): 617.

6. Hillary Kalmbach, "Social and Religious Change in Damascus: One Case of Female Islamic Religious Authority," British Journal of Middle Eastern Studies 35, no. 1 (April 2008): 51.

7. Qur'an 16:43 indicates the ulama's position of authority by saying that Muslims must consult on matters of knowledge those who know. The Prophetic tradition further implies their significant social status: "The ulama are the inheritors of the prophets." See Muhammad bin Isma'il al-Bukhari, Sahīh alBukhārī, "Book of Knowledge: Chapter: Knowledge Precedes Speech and Action," 1:5.

8. See Ira M. Lapidus, "The Separation of State and Religion in the Development of Early Islamic Society," Journal of Middle East Study 6 (1975): 369; Richard C. Martin, ed., The Encyclopedia of Islam and the Muslim World (New York: Macmillan Reference, 2004), 2:70-74.

9. Zaman argues that a constructive collaboration between the political leaders and religious authority existed under the Abbasids. For instance, Caliph Harun al- 
Rashid adopted positions and views prescribed by the contemporaneous religious scholars. His successor al-Ma'mun also complied with their advice in matters related to laws and religious life. See Muhammad Qasim Zaman, Religion and Politics under the Early 'Abbasids: The Emergence of the Proto-Sunni Elite (Leiden: Brill, 1997), 11-12. On the rivalry between the political authority of Islam and the religious authority under the Umayyads, see Patricia Crone and Martin Hinds, God's Caliph: Religious Authority in the First Centuries of Islam (Cambridge: Cambridge University Press, 1986), 21-23.

10. Ingrid Mattson, Can a Woman Be an Imam? Debating Form and Function in Muslim Women's Leadership, Sisters: Women, Religion, and Leadership in Christianity and Islam (ed. Scott Alexander), n.p: Sheed and Ward, 2007, 2.

11. The Qur'an refers to several women: Zaynab b. Jahsh (Q: 33:36), 'A'isha (Q: 24:23), and Khawla (Q: 58:1). Early Muslimahs were also cited for their roles in warfare, religious piety, and devotion, thereby serving as models for later generations. See Syed Sulaiman Nadwi, Heroic Deeds of Muslim Women (Lahore: Kashmiri Bazar, 1961), 7-15. For an overview on their contribution to scholarship, particularly hadith transmission during the thirteenth and fourteenth centuries (Damascus) and the twelfth century (Baghdad), see Asma Sayeed, "Muslim Women's Religious Education in Early and Classical Islam," Religion Compass 5, no. 3 (March 2011): 94-103; Asma Sayeed, "Women and Hadīth Transmission: Two Case Studies from Mamluk Damascus," Studia Islamica 95 (2002): 71-94.

12. Ruth Roded, Women in Islamic Biographical Collections from Ibn Sa'ad to Who's Who (Boulder: Lynne Rienner Publishers, 1994), 27-28.

13. Al-Shafi'i (d. 820) had a female hadith teacher, namely, Nafïsa bint al-Hassan, as did the hadith scholars al-Khatib al-Baghdadi (d. 1071) and al-Bukhari (d. 870). See ibid., 65-67.

14. Ibid., 135.

15. Hillary Kalmbach, "Social and Religious Change in Damascus: One Case of Female Islamic Religious Authority," British Journal of Middle Eastern Studies 35, no. 1 (April 2008): 37-39.

16. Riffat Hassan argued that female educators of Islam necessarily posit themselves in the public roles, a position that many patriarchal men resist and view as threat of westernization. See Riffat Hassan, "Challenging the Stereotypes of Fundamentalism: An Islamic Feminist Perspective,” Muslim World 91, nos. 1-2 (2001): 1-3.

17. For further reading on Malaysian women during this period, see Mohamad Abu Bakar, "Pemodenan, Pengislaman dan Pembebasan Wanita Melayu," Tamadun Melayu, ed. Ismail Hussein, A. Aziz Deraman, and Abd. Rahman al-Mahdi (Kuala Lumpur: Dewan Bahasa dan Pustaka, 1993), 334.

18. The Malaysian Constitution defines Malay as "a person who speaks the Malay language, practices the religion of Islam and habitually dresses and lives as a 
Malay." See Richard Winstedt, The Malays: A Cultural History (Singapore: Graham Brash [Pte] Ltd., 1961), 186.

19. A veil that covers the whole body, except her eyes. Malaysian women generally prefer bright and colorful scarfs that cover the hair and neck; however, lately women wearing that purdah have become noticeable.

20. Abu Bakar, "Pemodenan," 335. Unless otherwise noted, all translations into English are my own.

21. Zainal Abidin Ahmad, "Malay Manners and Etiquette," Journal of the Malayan Branch of the Royal Asiatic Society 23 (August 1950): 360.

22. For more on the struggle of women in politics during the early twentieth century, see Zaiton Ghani, "Wanita Melayu Dalam Politik 1946-1948," Sejarah Masyarakat Melayu Moden, (ed.) Khoo Kay Kim (Kuala Lumpur: Universiti Malaya, 1990), 210 and Abu Bakar, "Pemodenan," 337.

23. Raja Rohana Raja Mamat, The Role and Status of Malay Women in Malaysia: Social and Legal Perspectives (Kuala Lumpur: Dewan Bahasa dan Pustaka, 1991), 36.

24. For the historical survey of female education in post-World War II Malaysia, see Abdul Aziz Mat Ton, "Persekolahan Melayu 1945-1948: Satu Manifestasi Semangat Perjuangan Melayu," Sejarah Masyarakat Melayu Moden, 234-35.

25. http://www.mohe.gov.my/web_statistik/perangkaan_2010.pdf, date retrieved: $11 / 8 / 2015$.

26. Akiko Kamogawa, "Higher Education Reform: Challenges towards a Knowledge Society in Malaysia," African and Asian Studies 2, no. 4 (2003): 555-56.

27. Mek Siti Hussin and Aminah Mohd. Nasir, "Isu-isu Penting (Awal 1950-an) Dari Kaca Mata Akhbar Majlis dan Melayu Raya," Sejarah Masyarakat Melayu Moden, 259-61.

28. Abu Bakar, "Pemodenan," 342-43.

29. Abdul Aziz Bari, "Religion, Law, and Governance in Malaysia," Islam and Civilisational Renewal 1, no. 2 (October 2010): 61.

30. During the late eighteenth and early twentieth centuries, the various sultanates and the British signed several treaties in which the sultans were obliged to comply with the British officers' advice. The British colonial administration also established the state councils that would advise the sultans on matters related to Islam and Malay customs. See ibid., 63.

31. William R. Roff, Studies on Islam and Society in Southeast Asia (Singapore: National University of Singapore Press, 2009), 99.

32. The Yang Di Pertuan Agong is the constitutional Head of Islam in those Malaysian states that do not have a monarchy (i.e., Penang, Malacca, Sabah, Sarawak, and the Federal Territories of Kuala Lumpur and Labuan). For those states that do have a monarchy, this function is fulfilled by the sultan.

33. Roff, Studies, 103.

34. For a clear idea on its history and functions of JAKIM, see http:/www.islam. gov.my/en, date retrieved: 12/24/2015. 
35. Gerhard Hoffstaedter, Modern Muslim Identities: Negotiating Religion and Ethnicity in Malaysia (Copenhagen: NIAS Press, 2011), 72.

36. For the debates on the periods and forms of Islamic resurgence in Malaysia, see Hussin Mutalib, Islam in Malaysia: From Revivalism to Islamic State? (Singapore: Singapore University Press, 1993), 28-29; Julian C. H. Lee, Islamization and Activism in Malaysia (Singapore: ISEAS, 2010), 17.

37. For further elaboration on factors that facilitated Islamization in Malaysia, see Hussin Mutalib, Islam in Malaysia, 28-29 1993; Lee, Islamization and Activism, 17.

38. Hussin Mutalib, Islam in Malaysia, 2.

39. For illustrations on Islamization's manifestations in Malaysian society, both at the private and the societal levels, see Chandra Muzaffar, "Malaysia: Islamic Resurgence and the Question of Development," Sojourn: Journal of Social Issues in Southeast Asia 1, no. 1 (February 1986): 59-60.

40. Dakwah (preaching) activities in Malaysia can be traced from the Muslim students' activism during the 1970s as a part of spiritual renewal. For further reading on the connotations of dakwah and the nature of its activism, see Shamsul A.B., "Inventing Certainties: The Dakwah Persona in Malaysia," The Pursuit on Certainties: Religious and Cultural Formulations, ed. Wendy James (London: Routledge, 1995), 112-33; Sylva Frisk, Submitting to God: Women and Islam in Urban Malaysia (Copenhagen: NIAS Press, 2009), 5560. eBook Academic Collection (EBSCOhost), EBSCOhost (accessed October 30, 2015).

41. Unlike the traditional method used by scholars to teach Islam at mosques, schools, and private homes, contemporary Muslim preachers use mass media. Among the first well known Muslim preachers to appear on television during the late 1970s was the Egyptian shaykh Muhammad Mutawalli al-Sha'rawi (1911-1998). This global phenomenon of the "mass educating" of Islam is seen in Egypt (Amr Khalid), Niger (Abdul Aziz Amadou [a.k.a. Alarama]), Indonesia (Aa Gymnastiar), and throughout the Muslim world. For further reading on such preachers, see C. W. Watson, “A Popular Indonesian Preacher: The Significance of Aa Gymnastiar," The Journal of the Royal Anthropological Institute 11, no. 4 (December 2005): 773-92; Abdoulaye Sounaye, "Alarama Is All at Once: Preacher, Media 'Savvy,' and Religious Entrepreneur in Niamey," Journal of African Cultural Studies 25, no. 1 (2013): 88-102; Aaron Rock, “Amr Khaled: From Da'wa to Political and Religious Leadership," British Journal of Middle Eastern Studies 37, no. 1 (April 2010): 15-37.

42. In 1988, the Malaysian government announced that several hours on its radio and television (RTM) would be allocated for Islamic-related programs. See $\mathrm{Mu}-$ talib, Islam in Malaysia, $\mathrm{x}$.

43. Muzaffar, "Malaysia," 58.

44. Surau, like zāwiyah in Egypt, is a generic name for a place of worship in Malaysia, Sumatra, and Pattani. It is smaller than a mosque and never hosts the 
Friday congregational prayer. See R. A. Kern, "The Origin of the Malay Surau," Journal of the Malayan Branch of the Royal Asiatic Society 29, no. 1 (May 1956): 180-81.

45. For further reading on the process of authorization by JAIS (Selangor State Religious Council) and its purposes, see http://tauliah.jais.gov.my, date retrieved: 9/28/2015.

46. The penalty for unauthorized teaching of Islam, a fine and imprisonment, varies slightly from state to state. Generally, the fine ranges between RM 3,000 and RM 5,000 , and the imprisonment between two and three years - or both. See Muhammad Khusrin Munawi, "Tauliah Elak Penyelewengan," Utusan Online, September 7, 2009, http://ww1.utusan.com.my/utusan/info.asp?y=2009\& dt=1107\& pub=Utusan_Malaysia\&sec=Rencana\&pg=re_01.htm, date retrieved: 9/14/2015.

47. http://tauliah.jais.gov.my/, date retrived: 9/28/2015.

48. Muhammad Asri Zainul Abidin (a.k.a. Dr. Maza; b. 1971) is a young influential Muslim scholar in Malaysia. The youngest mufti ever appointed in the country - he was only thirty-five years old - he was reappointed in 2015 by the northern state of Perlis. He has been very vocal toward some of the interpretations of Islam in Malaysia and calls for renewing the Muslim mindset and way of thinking. He contends that all Muslims practices must be founded upon the reliable authentic sources of Islam, which requires that certain existing practices be reinterpreted. Based on such radical calls, his opponents accuse him of lacking tolerance as regards other interpretations and label him as subscribing to "Saudi Wahhabism." Despite this, however, his ideas remain admired and widespread, especially among the young educated class. Politically, he claims to remain neutral. See http://drmaza.com/home/?page_id=585, date retrieved 10/22/2015.

49. On his website, Asri states that he has a B.A., M.A., and Ph.D. in Islamic studies from credible universities in Malaysia and abroad. See http://drmaza.com/home/ ?page id=585, date retrieved: 9/28/2015.

50. http://blogs.wsj.com/dispatch/2011/08/22/qa-muhammad-asri-zainul-abidin, date retrieved: 9/14/2015.

51. As regards Islamic laws, specific Islamic bodies (e.g., the Islamic Religious Council [Majlis Agama Islam], the Office of the Mufti, and the Islamic Legal Consultative Committee) claim to both control religious interpretation and to administer the laws. See Tamir Moustafa, "Islamic Law, Women's Rights, and Popular Legal Consciousness in Malaysia," Law and Social Inquiry 38, no. 1 (winter 2013): 168-88.

52. However, women are allowed to lead religious think tanks, such as the Institut Kefahaman Islam Malaysia (The Institute of Understanding of Islam), which is under the purview of the Ministry of Prime Minister. Its female directors were Prof. Dato' Sri Zaleha Kamaruddin (2009-11) and Prof. Datin Dr. Azizan binti Baharuddin (2011-present). In addition, in 2010 the Federal Territory Sharia court appointed two female judges. See Magaji Chiroma Ibrahim, Ahmad Ma- 
hamad Bin Abdul Arifin, Haseeb Ansari, and Mohammad Asmadi Abdullah, "The Concept of Fatwa (Islamic Verdict) in Malaysia and the Constitutional Dilemma: A Legislation or Legal Opinion?" International Journal of Business, Economics, and Law 4, no. 3 June 2014): 19.

53. http://myislammedia.com/2014/05/biodata-ustazah-siti-nor-bahyah-mahmood. $\mathrm{html}$, date retrieved 10/22/2015.

54. http://umexpert.um.edu.my/sashsiaq, date retrieved 10/22/2015.

55. The following information on Fatmaa is based on the author's telephone conversation with her on October 25, 2015.

56. Al-Islam (January 2006): 36; al-Islam (November 2002): 44-47; al-Islam 343 (July 2002): 20-23; Anis (July 2001): 17.

57. Sharifah Hayati related that her involvement in preaching was the result of a coincidence. She was approached by a media person who was looking for a resourceful person to deal with issues related to Islam. See http://adik2ku. islam.gov.my/juri/27-prof-madya-dr-sharifah-hayati-syed-ismail.html, date retrieved: $9 / 8 / 2015$.

58. Al-Islam (January 2006): 36. One of the narrations often quoted by preachers to show the Prophet was an accommodative and independent husband was that he cleaned and mended his own clothes and shoes. Narrated by Imam Ahmad ibn Hanbal in Al-Musnād, 6/121; Sahīh al-Jāmi,' 4927.

59. It seems that her husband, who co-owns their consultation company, was sometimes invited to be on the panel with her.

60. The verses reads: "Behold, it is from Solomon, and it says, 'In the name of God, The Most Gracious, The Dispenser of Grace. [God says:] Exalt not yourselves against Me, but come unto Me in willing surrender!" She added: "O you nobles! Give me your opinion on the problem with which I am now faced. I would never make a [weighty] decision unless you are present with me." They answered: "We are endowed with power and with mighty prowess in war - but the command is thine; consider, then, what thou wouldst command" (Muhammad Asad translation).

61. See https://www.youtube.com/watch?v=HYME-7dQ4NI.

62. During their cruise trip for dolphin watching in the Maldives, Nor Bahyah and husband were told that it would very hard to get the dolphins to come closer to the cruise ship. They were convinced that after her husband's recitation of the verses, the dolphins did come closer and attributed this to the verses' miraculous aspect. See https://www.youtube.com/watch?v=HYME-7dQ4NI.

63. https://www.youtube.com/watch?v=EBjU7oEPM78.

64. Here Hayati quoted the meaning of blessing (barakah) in Arabic. https://www. youtube.com/watch? $\mathrm{v}=\mathrm{qMmrYuyQo8g}$.

65. Al-Sijistani, Sunan Abū Dawūd, "Chapter of Clothing," hadith nos. 4104 \& 1522.

66. http://pmr.penerangan.gov.my/index.php?option=com_content\&view=article $\& \mathrm{id}=4064: 15$-jul-tudung-pelengkap-gaya\&catid $=366: 2009-07 \&$ Itemid $=27$, accessed on 17 July 2009. 
67. She quoted Q. 18:7, in which God says that everything is made to be glittering show for humans and that they will be tested with that. See Suria Janib and Helyatulhuda Ibrahim, "Rahsia Kecantikkan Hakiki," Muslimah (August 2002): 17.

68. It is very difficult to prove that they got married, for the Qur'an does not mention it. The Qur'anic narration on her in Sürah Yüsuf disappears after she declares his innocence. Due to the absence of explicit evidence in the Qur'anic text, many scholars view their marriage as no more than a legend.

69. Janib and Ibrahim, "Rahsia kecantikkan Hakiki," 20-21.

70. Here Fatmaa was seen holding a book in front of her. It is not uncommon for a preacher to refer to a particular book when speaking to the audience. She informed the author that among the works she consults are the exegetical works of al-Tabari, Ibn Kathir, Sayyid Qutb, and others.

71. For an extensive account on the slander, see Ibn Kathir, Tafsìr al-Qur'ān al'Ażim (Beirut: Dar Ihya' al-Turath al-'Arabi, 1997), 3:238-42.

72. https://www.youtube.com/watch?v=XzXGlcKxfHk.

73. "And then eat of all manner of fruit, and follow humbly the paths ordained for thee by thy Sustainer. [And lo!] there issues from within these [bees] a fluid of many hues, wherein there is health for man. In all this, behold, there is a message indeed for people who think" (Muhammad Asad translation).

74. "Thus, step by step, We bestow from on high through this Qur'an all that gives health [to the spirit] and is a grace unto those who believe [in Us], the while it only adds to the ruin of evildoers" (Muhammad Asad translation).

75. The translation of the verse reads: "Had We sent down this Qur'an on a mountain, verily, thou wouldst have seen it humble itself and cleave asunder for fear of Allah. Such are the similitudes which We propound to men, that they may reflect."

76. In general, those verses call attention to the fact that the Qur'an was revealed to remind humanity about its Creator, Allah the Almighty, who is Most Compassionate to them and is the Creator and the Owner the world.

77. Zaila Muhammad Ali, "Suami Serah saya Kepada Allah," Anis (July 2001): 15.

78. Norhashimah Abdul Rahman, "Zikir Benteng Diri Remaja," Anis (December 2001): 2 .

79. She neither provides the reference nor mentions the status of this particular narration. One assumes that since her public audience mainly focuses far more on knowledge and understanding than its epistemological origins, its status does not need to be mentioned.

80. Author's personal interview with Sharifah Hayati at her office, Academy of Islamic Studies, University of Malaya, Malaysia, April 27, 2010.

81. Mahmood, Politics of Piety, 89.

82. Khaled Abou El Fadl, Speaking in God's Name: Islamic Law, Authority and Women (Oxford: One World Publications, 2001), 18. 
83. Fatmaa spoke about this during her telephone conversation with the author, dated October 25, 2015. The hadith mentioned here is from Sahị Muslim.

84. Al-Islam (October 2002): 24; al-Islam (June 2001): 330.

85. Liz Gooch, "In Malaysia, Reality TV with a Feminist Twist," The International Herald Tribune, November 21, 2011.

86. Zaila, "Suami Serah Saya Kepada Allah," 14-16.

87. Al-Islam (October 2002): 24; al-Islam (June 2001): 330.

88. Mahmood, Politics of Piety, 30.

89. Meriem El Haitami, "Restructuring Female Religious Authority: State-Sponsored Women Religious Guides (murshidāt) and Scholars ( 'älimāt) in Contemporary Morocco," Mediterranean Studies 20, no. 2 (2012): 234.

90. Jouili and Amir-Moazami, "Knowledge, Empowerment, and Religious Authority," 620.

91. Ibid., 619-20.

92. "Pendakwah Wanita Mahu peranan Diperkasa," Utusan Malaysia, May 24, 2012, 7.

93. Gooch, "In Malaysia."

94. A. Martinez, "The Islamic State or the State of Islam in Malaysia," Contemporary Southeast Asia 23, no. 3 (2001): 474-503. 